DEMOGRAPHIC RESEARCH

VOLUME 36, ARTICLE 53, PAGES 1637-1666 PUBLISHED 18 MAY 2017

http://www.demographic-research.org/Volumes/Vol36/53/

DOI: 10.4054/DemRes.2017.36.53

Research Article

\title{
On the normative foundations of marriage and cohabitation: Results from group discussions in eastern and western Germany
}

\author{
Andreas Klärner \\ André Knabe
}

(C) 2017 Andreas Klärner \& André Knabe.

This open-access work is published under the terms of the Creative Commons Attribution NonCommercial License 2.0 Germany, which permits use, reproduction \& distribution in any medium for non-commercial purposes, provided the original author(s) and source are given credit. See http:// creativecommons.org/licenses/by-nc/2.0/de/ 


\section{Contents}

1 The decline in the inclination to marry and the rise in nonmarital 1638 births

2 Theoretical considerations: Values, norms, and social change 1639

3 Value changes and the institution of marriage 1640

$4 \quad$ Marriage and family in eastern and western Germany 1642

$5 \quad$ Methods and sample 1645

5.1 Background: The cities of Rostock (eastern Germany) and Lübeck 1646

5.2 The sample 1646

$\begin{array}{lll}5.3 & \text { The focus group interviews } & 1647\end{array}$

$\begin{array}{lll}5.4 & \text { Data analysis } & 1647\end{array}$

6 Results 1648

6.1 The eastern German focus groups 1650

6.2 The western German focus groups 1653

$7 \quad$ Summary and discussion 1656

$\begin{array}{ll}\text { Acknowledgements } & 1659\end{array}$

$\begin{array}{ll}\text { References } & 1661\end{array}$ 


\title{
On the normative foundations of marriage and cohabitation: Results from group discussions in eastern and western Germany
}

\author{
Andreas Klärner ${ }^{1}$
}

André Knabe ${ }^{2}$

\begin{abstract}
BACKGROUND

Since the 1960s the inclination to get married has been declining in almost all western industrialised countries. Partnership arrangements have become more diverse and the share of cohabiting couples and nonmarital births has been increasing. Yet there are substantial regional differences in marriage and childbearing patterns, and the differences between eastern and western Germany are especially striking. We assume those differences can be partially explained by social norms and different attitudes towards marriage, cohabitation, and childbearing.
\end{abstract}

\section{OBJECTIVE}

We explore the views and values young people in eastern and western Germany hold about marriage, cohabitation, and childbearing and how those views relate to individual life experiences. We also examine different social norms and contexts in both parts of the country.

\section{METHODS}

We analyse data from qualitative focus group interviews conducted in in Rostock (eastern Germany) and Lübeck (western Germany) with women and men aged 25-40.

\section{RESULTS}

Our findings indicate that there are normative differences between eastern and western Germans in their attitudes towards partnership, marriage, and family formation that can be traced back to the social and political conditions prior to German unification in 1990. The harmonisation of family laws and policies across Germany after 1990 did not automatically lead to a convergence in the norms and behaviours of the people living in these two regions.

\footnotetext{
${ }^{1}$ Thünen Institute of Rural Studies, Germany. E-Mail: andreas.klaerner@thuenen.de.

${ }^{2}$ University of Rostock, Germany. E-Mail: andre.knabe@uni-rostock.de.
} 


\section{The decline in the inclination to marry and the rise in nonmarital births}

Marriage rates have been declining and rates of nonmarital births have been rising in almost all western industrialised countries since the 1960s (Kiernan 2004; Perelli-Harris et al. 2012). Increasingly, phases of nonmarital cohabitation are playing a larger role not only in the biographies of individuals but also in the institutionalisation process of partnerships (Treas, Lui, and Gubernskaya 2014). Both Heuveline and Timberlake (2004) and Holland (2013) have shown that the function and meaning of cohabitation and marriage have become more diverse and pluralised.

These trends have been accompanied by increasing social acceptance of nonmarital childbearing and unconventional lifestyles and family forms, including single-parent families, 'living apart together' partnerships, married couples who are child-free by choice, 'patchwork families', same-sex partnerships with children, and heterosexual nonmarital cohabiting unions with children (Sobotka and Toulemon 2008).

While this general trend towards an emergence of diverse partnership forms and a decline in the importance placed on marriage has been observed in all westernEuropean-influenced countries, substantial regional differences in marriage patterns remain (Kalmijn 2007; Perelli-Harris and Lyons-Amos 2015). These differences are especially clear when we look at the share of births that are nonmarital. According to data from Eurostat, the percentage of live births in the European Union that occurred outside of marriage ranged between 7.6\% (Greece) and 57.6\% (Slovenia) in 2012, while the average share for the 28 countries of the European Union was $40.2 \%$.

When we take a closer look we can see that in international comparisons the differences between eastern and western Germany are especially striking. In 2012 $28.4 \%$ of all births in western Germany were nonmarital, whereas in eastern Germany the share was 58.8\% (Data from the German Federal Institute for Population Research; own calculation). This gap is remarkable, because although the two parts of Germany had separate economic and political systems between 1945 and 1990, the eastern and western regions of the country have been subject to the same legal framework since 1990. Thus, it appears that factors other than the legal framework are affecting the nonmarital birth rate, particularly differences in values and norms regarding marriage and family formation (Bernardi, Klärner, and von der Lippe 2008, Arránz Becker, Lois, and Nauck 2010; Klärner and Keim 2011; Klüsener and Goldstein 2014).

Following Giddens' (2013) theory of structuration, we assume that marital behaviour is influenced by structures (law, tradition, norms and values, social change) that are reproduced and transformed in everyday life. Action, e.g., the decision whether or not to marry, occurs and becomes rational within these structural contexts of 
everyday life. In order to understand the multiple dimensions of these rationalities, we want to ask how people translate contextual and macrostructural changes (interpreted in the light of traditionalised norms and values) into action. In our article we address the following questions: 1) Which norms and values regarding marriage and cohabitation are most prevalent in eastern and western Germany? 2) How are these norms and values negotiated? and 3) What are the underlying (historical) behavioural rationales for these attitudes?

Our analysis is based on qualitative focus group interviews with a total of 137 participants. We conducted these interviews in 2012/2013 in the eastern Germany city of Rostock and in the western German city of Lübeck.

In the following we first provide an overview of the theoretical discussions surrounding societal value changes and the institution of marriage, and then present research results on the differences between the norms and values of family formation in eastern and western Germany. We then introduce the methods used in conducting our group discussions, and describe our sample. Next, we present the results of our analysis of the discussion groups. Finally, we place our findings in the context of international and German debates.

\section{Theoretical considerations: Values, norms, and social change}

In our analysis of the meaning of norms and values for the different regional and cultural dynamics in the rise of nonmarital unions, we refer to Anthony Giddens' theory of structuration (2013). According to this theory the general values in a specific society are relatively long-lasting phenomena, but the behavioural norms associated with these values - such as those that regulate marriage - must prove to be useful in practice, and are constantly being reproduced, updated, and modified through behaviour. Unlike in normative paradigms, in which values and norms are seen as the basis for behaviour, Giddens prefers to use more flexible terms like 'routines' and 'regularities', because 'agency' and 'structure' are closely interrelated. In this context, Giddens refers to his concept of the duality of structure: agency is influenced by - and dependent on structure (like values and norms), but structures grow and change out of agency (which is based on former structures, and so on). Our conception of norms and values is based on this perspective, and allows us to explain not just the reproduction of structures but also their transformation.

Whereas, according to Giddens, the reproduction of societal structures occurs largely through the unquestioned copying of traditional behavioural patterns (practical consciousness), modification processes may occur when there are conflicts between conventional and alternative behaviours. Such conflicts can cause individuals to reflect 
upon traditional models (discursive consciousness). The borderline between types of consciousness is fluid. An individual may become irritated when a planned or unintentional change affects the social environment - as a result of, for example, a change in the legal or institutional conditions. The individual is challenged to adapt his/her behaviour to those conditions, and thus to deviate from his/her familiar behavioural pattern. At such moments, questions are asked regarding the degree to which these norms remain useful and practical and whether a new set of actions is needed. The individual is therefore forced to reflect upon his/her modes of behaviour, and to consider modifying them accordingly.

It is not difficult to see how this process could be applicable to Germany, as the societal and political conditions that influence individual decisions changed abruptly in 1989/90. These revolutionary changes had the greatest impact in eastern Germany (the former German Democratic Republic (GDR)), but they also influenced society and the social order in western Germany (the Federal Republic of Germany (FRG)). Against this background, we first investigate the roles that values and norms generally play with regard to demographic behaviour. We then take a closer look at the marriage and cohabitation norms and values that emerged under the specific conditions of the political and social systems of the GDR and the FRG. We assess the relevance of these political and socioeconomic norms and values, and examine updates and modifications as conditions continue to change.

\section{Value changes and the institution of marriage}

The role played by values and norms in the differences between and changes in a variety of demographic behaviours was emphasised by the theory of societal value change (Inglehart 1977), which led to the development of the theory of the so-called Second Demographic Transition (SDT; van de Kaa 1987). The SDT posits that a change in norms and values is triggered by a series of societal modernisation processes, and that this transition is in turn associated with a range of overlapping processes, including a sub-replacement-level birth rate, the spread of a variety of nonmarital forms of living and partnership arrangements, and the dissolution of the close link between marriage and family formation (van de Kaa 1987, 2001; Lesthaeghe 2010, 2011). In demographic discussions the role played by values and norms in decisions regarding parenthood and marriage has been increasingly recognised (Perelli-Harris et al. 2014; Liefbroer, Merz, and Testa 2015). According to this view, the rapid increase in material wealth and societal liberalisation processes has led to a generational change in which materialistic values are replaced by postmaterialistic, postmodern, or individualistic values. These values are seen as inconsistent with the morally and legally binding 
characteristics of marriage, and are thus considered responsible for the growing number of people who have chosen not to marry, or even to remain single, over the long term (van de Kaa 2001; Surkyn and Lesthaege 2004; Lesthaege 2010).

At the very least, traditional marriage - i.e., an institutionalised, lifelong, monogamous union of a man and a woman with (marital) children - today can no longer be conceived of as an obvious, unquestioned, and exclusive institution. Individuals now have a range of competing lifestyle options, including choices about whether to have a partner or to have children. Thus, both couples and individuals now have to make active decisions about partnership and family formation (Beck-Gernsheim 2002). It therefore appears that not only has marriage become less important but also different meanings are assigned to the institution of marriage, and individual and societal attitudes towards nonmarital unions (cohabitation) have changed (Thornton, Axinn, and Xie 2007; Hiekel, Liefbroer, and Poortman 2014).

Accordingly, Holland (2013) analyses sequences of marriage and childbirth in the life course, based on the data of 1,396,305 Swedish women born between 1950 and 1977, and finds three different ideal types of marriage: 1) legitimising marriage: marriage is seen as a precondition for giving birth to a child; couples marry before or at least shortly after the birth of the first child; 2) reinforcing marriage: couples decide to marry after the birth of the first child and before the birth of further children because they want to achieve additional security and stability; and 3) capstone marriage: the family formation is finished by the marriage of the parents after the birth of their children. Holland (2013) argues that marriage is still relevant in Sweden, although she finds increasing diversity in the meaning of marriage. As the 'legitimising marriage' becomes less relevant among the younger age groups, 'reinforcing' or 'capstone' marriages gain influence across the other age groups.

Investigating the association between cohabitation and marriage, Heuveline and Timberlake (2004) analyse data from 16 industrialised nations and find four ideal types. The role of cohabitation is 1) marginal in countries where only a small minority of couples cohabit in unmarried relationships (Italy, Poland, Spain); 2) a prelude to marriage where unmarried cohabitation is a test phase before marriage and the birth of the first child (e.g., Belgium, Hungary); 3) a stage in the marriage process where family formation usually leads to married parenthood but the timing of cohabitation, marriage, and giving birth to a child is not fixed (e.g., Austria, Finland); and 4) an alternative to marriage where unmarried cohabitation and parenthood are seen as one possible choice and to marry as another (Canada, France) or where marriage is indistinguishable from cohabitation (Sweden). According to Heuveline and Timberlake, Germany belongs to the third group, but there are reasons to question this. The data used in the paper was collected at the beginning of the 1990s (in Germany, 1992), which was too early to analyse adaptive behaviour by eastern Germans after reunification. Additionally, the 
beginning of the 1990s marks a very special period of time because of the phenomenon of 'lowest low fertility' in the postcommunist states after the collapse of the Soviet Union. Therefore the results for eastern Germany cannot be generalised. Finally, the authors do not distinguish between eastern and western Germany, which at that point in time would have yielded very different results.

\section{Marriage and family in eastern and western Germany}

Eastern and western Germany share a common history, language, and cultural traditions, but were divided into different nation states after the Second World War and subject to antagonistic political and economic regimes. The Federal Republic of Germany (FRG) was established in the western German regions, where a democratic, conservative welfare state evolved. In eastern Germany, in the German Democratic Republic (GDR), a totalitarian socialist regime came into power. The FRG and the GDR developed different, not to say antagonistic social and cultural systems that affected all areas of individual and social life. Thus it is justifiable to speak of different family and fertility regimes (Kreyenfeld 2004; Leitner, Ostner, and Schmitt 2008). After the fall of the Berlin Wall in 1989 and reunification, the former GDR immediately adopted the institutions of the FRG, and both social context and economic and political institutions literally changed from one minute to the next.

The quasi-standardized family model in former West Germany consisted of a male breadwinner and a housewife who, after marriage or giving birth to her first child, managed the household and the children, and often did not return to her profession. This model was, and is, subsidized by the state, e.g., through tax benefits (Pfau-Effinger and Smidt 2011). This concept of family roles was slow to change. The social upheavals of 1968 and the re-emergent feminist movement of the 1970s/1980s ('emancipation from below') questioned 'traditional' gender roles. Growing educational participation of women, a shortage of skilled labour, and men increasingly wanting "active fatherhood" (Werneck, Beham, and Palz 2006) led to higher employment of mothers, and increasing engagement of fathers in tasks relating to the care and upbringing of children (Holst and Schupp 2001; Trappe and Sørensen 2006). However, the traditional male breadwinner model - which is still favoured through tax privileges for married couples with one main earner - has proven to be very stable in practice, and gender differences persist.

In the GDR, regulatory actions successfully forced a different family model ('emancipation from above'). The standard was the two-income family: mothers interrupted employment only briefly, part-time work was less common, and mothers seeking to reduce working hours were pressurized to justify their decision (Trappe 1995; Falk and Schaeper 2001). Accordingly, in 1989 82\% of women in the GDR were 
in employment (mostly full-time), but only 56\% in the FRG (mostly part-time) (Hülser 1996). Though high female labour participation is an important aspect of gender mainstreaming, gender roles were still unequal in the GDR and women bore the main responsibility for the family and household in addition to being gainfully employed (Kolinsky 2003; Schmitt and Trappe 2010).

There remain differences between eastern and western Germany in family formation patterns (cf. Konietzka and Kreyenfeld 2004; Huinink, Kreyenfeld, and Trappe 2012; Bastin, Kreyenfeld, and Schnor 2013). Eastern Germany is characterized by fewer childless women, more children born out of wedlock, and a lower age at first birth for mothers. Also prevalent are more pregnancies in insecure economic circumstances or when mothers are still in the educational system.

A shift in the meaning of marriage has been discussed not only for East Germany (GDR) where the reunification led to a sudden replacement of family policy, but also for West Germany (FRG) since the end of the 1980s. For example, Nave-Herz (1989) argues that couples increasingly marry not for convenience or mutual support but to ensure that their children are supported, and thus wait to get married until they are planning children or have a child on the way (Peuckert 2012: 41f.). But whether this assumption can be applied to Germany has been questioned. In the early 1990s, Vaskovics and Rupp (1995) surveyed married couples in eastern and western Germany and found an increasing trend towards a decoupling of marriage and family formation. Their findings indicated that while love is considered the most important prerequisite for marriage in the east and the west, most respondents agreed that other motives were needed to justify getting married. While the (impending) birth of a child was among these reasons, it was not seen as particularly important.

The work of Schneider and Rüger (2007) generates new insights into the meaning of marriage in Germany. Based on their survey of 377 couples that married between 1999 and 2005, they identify three main groups of motives for marriage, distributed roughly equally across the respondents. While marrying for the sake of the children is among the motives cited, this reason is assigned to the category of "utility-oriented marriage motives", which also includes reasons such as financial advantages and the desire to minimise partners' physical separation. Thus, it is assumed that the couples who married because they had children did so for practical reasons. The other categories are "value-oriented marriage motives", or marrying because the partners place a high value on marriage; and "spontaneous-emotional motives", or marrying for love or symbolic reasons. This study therefore shows that there is a range of motives for marrying other than starting a family. However, the question of the extent to which the motives for marrying differ between eastern and western Germans remains open.

To the best of our knowledge, no existing studies have investigated the meaning of marriage in eastern and western Germany from a comparative perspective. There has, 
however, been some research into the different family models (Familienleitbilder, Diabaté and Lück 2014; Schneider, Diabaté, and Ruckdeschel 2015) and gender roles in the two parts of the country. Especially large differences between eastern and western Germany have been found when couples with children are examined. For western Germany the male breadwinner model is frequently assumed to be dominant; i.e., the male partner is the main earner while the wife and mother is not in paid employment or, in a modernised version of this model, is employed part-time (Nave-Herz 2001; PfauEffinger and Geissler 2002; Rüling 2007; Bernardi, Klärner, and von der Lippe 2008; Pollmann-Schult 2009; Konietzka and Kreyenfeld 2010; Schmitt and Trappe 2010; Klärner and Keim 2011; Hill and Kopp 2013). This model is based on the principle that marriage is an institution that provides security and order for cohabiting couples, and especially for those who have children. The birth of the first child is thus assumed to have important consequences for the individual life course plans of both the man and the woman, as well as for the division of paid and unpaid work within the partnership. Whereas, before they start a family, men and women may be expected to prioritise personal fulfilment and professional success, after they have children they are expected to put these goals aside in order to prioritise family norms and values. Thus, a retraditionalisation of gender roles and the institutionalisation of a gender-specific division of labour are anticipated.

By contrast, studies of eastern Germany have not revealed a single dominant lifestyle or partnership arrangement among couples, including among those with children (Huinink, Kreyenfeld, and Trappe 2012). Couples in eastern Germany tend to move in together at younger ages, and these cohabiting unions are less likely to end in marriage than they are in the west (Schnor 2014). This distinctive pattern has been attributed to the social and cultural characteristics of eastern German women (low levels of religiosity, high levels of career orientation) and the social and economic effects of reunification (low household income, reduced levels of life satisfaction; Arránz Becker, Lois, and Nauck 2010). In a comparison of the relationship stability of unmarried couples with a child in eastern and western Germany, cohabiting couples in eastern Germany have more stable relationships than cohabiting couples in the west (Schnor 2012). Thus, it appears that the societal context has considerable influence on the stability of relationships.

The qualitative findings of Bernardi, Klärner, and von der Lippe (2008) indicate that in eastern Germany family formation goals are pursued in parallel with career and personal development goals. Whereas in western Germany the sequencing of personal fulfilment and family formation is the normative model, in eastern Germany it is widely believed that individuals should try to strike a compromise between career and personal fulfilment on the one hand, and family on the other. Compared to their western German counterparts the eastern Germans interviewed were more likely to report that they try to 
balance the areas of family, work, and leisure and to find compromises between their specific goals and desires in these areas.

In terms of the division of labour within the family, the literature has shown that families that follow the male breadwinner model are relatively rare in the east (Schmitt and Trappe 2010). Because there is a more gender-equal distribution of paid and unpaid work among eastern German couples, women in the east tend to be relatively independent economically. However, Schmitt and Trappe (2010) emphasise that in eastern German families there is often a greater need for both the male and the female partner to contribute to the household income. As in the east employment opportunities are often insecure and many individuals have periods of unemployment, relying on the male breadwinner model may be seen as risky. However, whatever the region of origin and the labour force behavioural patterns in play, the work associated with reproduction and caring for children is likely to be divided along traditional gender lines (Träger 2009; Peuckert 2012).

These results seem to suggest there is a need for further research. Some of the existing findings are based on older data that was collected shortly after German reunification, other findings are not suitable for making east-west comparisons, while more recent evidence regarding the normative basis of marriage and cohabitation is only indirectly accessible through studies on similar topics.

To understand the persisting east-west differences in family formation on the one hand and the specific modes of change in both regions on the other, we need to have a closer look at the underlying norms and values and what they refer to. We ask, therefore, which norms and values regarding marriage and cohabitation are most prevalent in eastern and western Germany, how these norms and values are negotiated, and what the underlying (historical) behavioural rationales for these attitudes are. In the following section we explain why we consider focus group discussions suitable for investigating social norms and values, how we implemented this method in our study, and how we analysed the data.

\section{Methods and sample}

We analysed the results of qualitative focus group interviews with a total of 137 participants, which took place in 2012/2013 in the eastern Germany city of Rostock and in the western German city of Lübeck. The focus groups are part of a larger project which is designed to explain different patterns of family formation and partnership arrangements in European countries and to address different social norms regarding nontraditional family arrangements, such as cohabitation and nonmarital childbearing (Perelli-Harris et al. 2014). 
While the group discussion method is seldom used in social science research, we believe it to be a particularly suitable approach for investigating societal norms and the values that regulate behaviour (Bloor et al. 2001; Stewart, Shamdasani, and Rook 2007; Liamputtong 2011). This assumption is based on the premise that norms and values provide the structure for the social context, and cannot be observed in isolation from it. In a standardised discussion setting set apart from everyday life - as is often the case in standardised surveys, and even in open or guideline-based one-on-one interviews - the modes of action and the mechanisms that underlie norm-oriented behaviour cannot be reproduced. Norms are not fixed dimensions that can be captured using standard survey methodology: rather, they are reproduced, modified, or even generated through interactions. Based on this logic, we should attempt to survey norms and attitudes in settings that mimic everyday interactions as much as possible (see also Barbour 2007).

\subsection{Background: The cities of Rostock (eastern Germany) and Lübeck (western Germany)}

We held a total of 18 group discussions with individuals between the ages of 25 and 40 between March and April 2012 in Rostock, and between September and October 2013 in Lübeck. The two cities were chosen because they have similar social, historical, and structural backgrounds. They are Hanseatic cities on the Baltic Sea with predominantly Protestant populations. They have similar population sizes $(200,000$ for Rostock and 215,000 for Lübeck), and similar economic conditions (the unemployment rate in 2013 was $11.5 \%$ in Rostock and $10.4 \%$ in Lübeck). The main difference between the cities is that they had distinct political and economic systems when Germany was divided: Rostock was located in the socialist German Democratic Republic, while Lübeck was in the western-influenced democratic society of the Federal Republic of Germany.

\subsection{The sample}

Participants were recruited by a local market research institute which approached people on the streets and via telephone. We recruited participants between the ages of 25 and 40 . The decision to address this age group was made by the international team in order to focus on those more likely to be making partnership decisions for the first time. The team was less interested in cohabitation in later life or after divorce.

We interviewed eight groups in Rostock with a total of 74 participants who were born and raised in eastern Germany, and five groups in Lübeck with 31 participants in total who were born and raised in western Germany. Additionally, we conducted five 
mixed groups with 32 participants, born and raised either in eastern or western Germany, of which two groups had a majority of eastern German participants and three groups a majority of western German participants.

These focus groups were homogeneous with respect to gender and educational level, but we made special efforts to ensure the greatest possible heterogeneity among the groups in terms of age, family status, and number of children. Here we assumed that diversity would stimulate the conversation, encouraging the participants to take controversial positions in their discussions about marriage and cohabitation and leading them to explore the meaning of the norms that underlie these positions.

In sum, 137 persons attended our focus groups, whereof 89 men and women were born and raised in eastern Germany and 48 men and women born and raised in western Germany.

\subsection{The focus group interviews}

The course of the discussions followed guidelines in which the following themes were addressed: the general and the individual meaning of marriage, the advantages and disadvantages of cohabiting while married or unmarried, the reasons for and against getting married, the significance of children for the partnership and the decision to marry, and the legal framework of marriage. Each group had 5-10 participants and the discussions lasted between 60 and 90 minutes.

\subsection{Data analysis}

Data were analysed in an iterative process. Immediately following the focus group interview the research team met to debrief, summarise the contents of the group interview, and discuss the peculiarities of each group. Each member of the research team also took field notes during the focus groups. The recordings of the focus groups were transcribed verbatim. These transcripts were coded using the software package MaxQDA. We applied a two-fold coding strategy, using both a bottom-up coding procedure starting with open, in-vivo codes that then were summarized into broader categories, and a thematic coding procedure, coding text excerpts relating to relevant categories such as individualisation and economic uncertainty. These codes later helped in retrieving text excerpts, which were then analysed within the context of the focus group discussion.

The team wrote short portraits of each respondent, summarising biographical information and the content of their contributions to the group discussion. All people 
involved in the data analysis had taken part in conducting the focus groups, and native German speakers analysed the data.

We analysed norms and values specific to eastern and western Germany using the focus groups that were homogeneous with respect to the region of birth. To validate and cross check our findings, in a next step we analysed how differences in norms and values were discussed within the heterogeneous groups consisting of both eastern and western German participants. In our presentation of results we use only quotes from groups in which all of the respondents were either of eastern or western German origin.

\section{Results}

It should first be noted that in all of the groups it was seen as self-evident that a person would want to live with a partner more or less permanently. In our sample there were very few confirmed singles who did not want to be in a partnership. Yet marriage is far from being an unquestioned, institutionalized path for a partnership. The focus group discussions show that cohabitation is a socially acceptable way of life for a couple. We did not find open or even widespread disapproval of cohabitation in the discussions. Our respondents expressed that a social stigma attached to cohabitation was something belonging to the (long ago) past of their own parents or grandparents.

In this light, the decision to marry has to be made individually and very actively, and there have to be good reasons for marrying. Accordingly, our focus group participants mentioned a wide range of reasons for getting married (see Table 1). These reasons are not necessarily those of the participants themselves, but in some cases are reasons the participants imagined others might consider important. In Table 1 we present the motives or reasons for marriage we found in our focus groups.

Practical reasons to marry are mainly financial ("we got married for financial reasons"), especially getting married for tax benefits. The German tax system favours the division of labour between married partners in which one partner earns more than the other, by splitting the total income of both into equal shares. As a consequence the partner with the higher income is assigned to a more favourable tax class. Other practical reasons to marry are legal advantages regarding heritage, child custody, and a partner's right to decide in case of emergency ("assuming I have an accident, lay in hospital, where only immediate family are allowed to visit me, then she has no chance"). 
Table 1: The reasons for getting married mentioned in the group discussions

\begin{tabular}{ll}
\hline Practical considerations & Lower taxes \\
& Financial security, inheritance \\
& Child custody, recognition of paternity \\
& Protection for the child or children \\
& Protection from being transferred or dismissed at work \\
& Decision-making powers in case of emergency \\
\hline Emotional feelings & Love \\
& Fulfilling a childhood dream \\
& Experiencing a special event \\
& Being part of a proper family \\
& Having the same name \\
& Having a feeling of emotional safety \\
\hline Commitment to the partner & Making separation more difficult \\
& Having a mutual commitment as a couple \\
\hline Traditional obligations & Marriage as a prerequisite for the birth of the first child \\
& Religious motives \\
\hline
\end{tabular}

Practical considerations were often discussed in contrast with emotional feelings such as love ("we love each other and we wanted to make it known to everyone around us") and being a family ("I took my husband's name so that we act as a family also to the outside, everyone should recognise that we are a family now and we belong together").

If a partnership is seen as more serious than others, there is a desire to emphasise and strengthen the commitment to the partner through marriage ("When you are married, before you separate for trivial reasons, you are more likely to talk about the problem, and to say, 'Come, let's try it again"'. FE05- $08^{3}$ ).

One traditional motive for marriage was the belief that a couple should get married before the birth of their first child. Regardless of whether our respondents still believed getting married was a prerequisite for family formation, the concept that it should be was present in their minds, and they traced it back to the generations of their parents and grandparents: "If we were going to get pregnant, then we would not need to marry come hell or high water. But I am coming back to tradition, talking about marriage and then having a child that sounds like a unit for me. Why this is so? Perhaps, because it was exemplified to me."

In what follows we take a closer look at the differences in how the eastern and the western German focus groups discussed these motives.

\footnotetext{
${ }^{3}$ The identifying information for the group discussion participants can be broken down as follows: F/M $($ female/male $)+\mathrm{E} / \mathrm{W}$ (eastern/western Germany) + group number + participant number.
} 


\subsection{The eastern German focus groups}

In general, there was a relatively low desire to marry in the eastern German groups and many participants stated that they did not necessarily want to marry (see also Klärner 2015). As a justification, it was frequently mentioned that nowadays there is no need to be married in order to be happy and satisfied. Cohabitation was seen as a modern lifestyle, consistent with contemporary demands on individual freedom and independence and flexibility in the job market. Some participants even said that unmarried cohabitation is better than being married because love in cohabitation has to continuously be proved and developed and is not sealed permanently with a marriage certificate. Accordingly, it was suggested that the overall decline in the number of marriages is mainly caused by social change. Today, neither social pressure nor governmental constraints and incentives to follow a specific life course exist in (eastern) Germany. The tax benefits for married couples do not apply to the very common partnership model composed of two working partners with similar incomes. As a first explanation of the substantial change in marriage patterns, respondents mentioned the lack of legal benefits of marrying today in comparison to during the GDR period. Besides this, according to the participants, there are sociostructural and economic factors that negatively influence marriage plans and marriage behaviour, like career opportunities (especially for women) and/or longer periods of education that prevent some of them from marrying (at least at an early age).

What remain are the emotional motives to marry. It is particularly striking that in the groups of eastern German women, emotional feelings were mentioned as being the most decisive reasons for marriage. The few participants who said they would marry or had married for instrumental reasons were often criticised by the group and put on the defensive, as an example from a discussion group of eastern German women with low educational attainment shows. Participant FE06-17 explained that she and her partner had been talking about getting married for a while, but did not decide to do so until they had moved into a jointly owned house. She stated that "in principle, money was really the deciding factor" for marrying. Participant FE06-19 then responded by saying, "When I find the man of my dreams who gives me what I have always needed, then I will marry him, too." As it could be assumed that what the second participant was referring to when she used the term "give" was the "money" that Participant FE06-17 mentioned, she clarified that she was talking above all about the emotional aspects of the relationship, and thus quickly added, "Not the financial aspects. That's not it, I won't go down that path again, as I said, there's no guarantee. Instead, it would be for the feeling 'He wants me and I want him"'. Participant FE06-20 expressed her agreement and underlined the importance of this emotional motive in response to FE0617, saying, "It's also possible to do it out of love." Thus, the instrumental motives of FE06-17 were devalued, placing her in a defensive position. She tried to respond by 
emphasising the emotional side of her marriage, saying, "That's not the way it was with us, either, it just sounded that way. We love each other, too. We both had tears in our eyes and so forth. It was very beautiful and romantic." Then, however, she admitted that the money "was a big issue that made me say, okay, we should take the step".

Another participant (FE06-13) entered the discussion with the derisive remark, "Yay, tax class 4!" which was met with laughter from the other participants. At that point FE06-17 became aware that her argument for marriage from an instrumental perspective was not shared by the others, and threw in another provocative remark: "We didn't combine our names, each of us kept his own. We didn't even do that". In response FE06-13 launched into an almost passionate defence of the affectualemotional motives for marriage:

Getting married is not just something you do on a whim - 'Hey, we've got some time today, the registry office has a free appointment, honey, I have nothing better to do Friday afternoon, let's get married'. [...] People shouldn't get married because they are in the mood to do it, but because they really love each other, and because [...] they say to the other, 'I can really imagine going through life with you, through thick and thin, sickness and health. (FE06-13, female, 26, east, lower edu., in partnership, no children)

As is clear from the passages above, in the eastern German discussions there was considerable tension between the participants who cited practical considerations for getting married, and those who thought the emotional feelings were more important.

What these two groups of participants have in common is that they view marriage as an institution that has little meaning for everyday behaviour or for the social status of the partnership. The proponents of getting married because of emotional or romantic feelings see the legal and financial privileges associated with marriage as irrelevant. They enter into marriage as a confirmation of an existing union, not in order to change its day-to-day form. The proponents of practical reasons for marrying get married to gain access to financial or legal advantages, and not because they believe being married has an effect on their day-to-day behaviour within the relationship.

Marriage is seen as lacking in value and content, which is also why it can no longer be seen as having any practical basis. Several of the participants justified their perception that getting married is pointless by citing the discontinuation of institutional and financial incentives for marriage from the GDR era:

What marriage meant for our parents doesn't apply to us today. [...] I know that my parents got married because they were having a child, and would then get a flat. That's not the case anymore. Today I can choose my own flat. [...] 
that's the way it was in the GDR. There was the credit for couples with a large number of children, but you only got it if you were married. That was a real status, being married [...] To be someone, you had to be married. And that's been lost today. (FE02-38, female, 40, east, higher edu., divorced/single, one child)

The men in the eastern German discussion groups talked about their motives for getting married with much more emotional distance than the women. For the men, marriage was seen as one of many possible options. Among the reasons they cited for their ambivalence about getting married were changes in "the prevailing societal conditions", and that "these days it doesn't really matter how you live" (ME04-42). Another participant observed that people "really have the freedom to decide whether they want to live together with or without" a marriage certificate (ME04-42). Most of the participants agreed that since government incentives for getting married (early) no longer exist, and societal norms regarding the need to get married have changed, only personal reasons or preferences play a role in the decision whether or not to get married. At the same time, however, the participants agreed that the form of living arrangement chosen should be suitable for all of the people involved, including any children who might eventually be affected: "Having a stable relationship based on mutual respect is important for children. Whether or not the parents are married is less important" (ME07-18). This applies "even if the mother or the father has been replaced." Participant ME07-14 quickly concurred, saying, "Whether or not you are married doesn't make you a better or a worse father". Participant ME07-11 followed up on these remarks, saying: "For children I think it is important the relationship of the parents works reasonably well, even if they are separated. [...] if you have a stable relationship with your ex-partner, the children will be fine".

Unlike these individual motives to marry or not, considerations concerning commitment to the partner and traditional obligations were barely mentioned as relevant motives for marriage in the eastern German discussions. This became apparent in discussions about marriage and family formation. According to these discussions, parenthood is not seen as a coercive reason to marry, because having a child does not radically change the life of the individual or the couple in general. Mothers and fathers arrange family and work in the context of a high level of acceptance of working mothers and institutional childcare. FE06-16 summarised the views of the group of lesseducated women by rejecting the idea that life transitions have to follow a predetermined sequence: "I can have my child first and then get married, and work at the same time".

In the eastern German focus groups it becomes clear that decisions concerning couples' relationships, marriages, and especially decisions about whether to have a 
child, are made in conjunction with considerations about whether to pursue other goals, such as individual freedom and self-realisation:

I would also say, perhaps this has to do with individualisation of the people, generally, all became a bit selfish and want to fulfil themselves and due to that it is difficult to compromise. Especially in a marriage you have to. And if you are unattached, you can fulfil yourself, a marriage might be limiting in those terms. (FE03-17, female, 28, east, higher edu., single, no children).

In the case of women, these aspirations include the desire to remain financially independent of their partner. The factors that are most relevant to this decision are not which of the goals are most desirable, but rather which situation would allow the individual to strike a compromise between as many goals as possible.

\subsection{The western German focus groups}

Despite public debate about the loss of significance of marriage and rising divorce rates, there were still participants who believe in the institution of marriage in our western German focus groups. Many of them referred to (family) traditions and understood marriage as a special sign of love. The benefits of marriage are the protection of children or being a 'real' and 'correct' family, where all family members share the same name. In our western German sample, arguments for not marrying were mostly restricted to specific life situations. Individuals have not yet married because they do not feel ready for it, but they expect to marry later - or at least they do not exclude this option. Participants often emphasized missing the security and maturity necessary to take the step to marry. Cohabitation is seen as part of a premarital stage of life, which is characterized by a desire for self-fulfilment, and also for promiscuity - especially among men. The advantages of cohabitation are a reason not to marry: it is easier to maintain individual independence in a nonmarital partnership and even when cohabiting. This form of couple relationship eases separation and therefore allows meeting the requirements of modern society, such as temporal and spatial flexibility in the job market, and adapting to changes in life planning, as well as pursuing uncomplicated promiscuity.

Some of our participants were in favour of family and wanted to have children, but had not yet realized childbearing. These participants often wanted to lay a "foundation"

- in terms of financial security and a safe professional position - before considering having a child. Security, from a financial and emotional perspective, played an extraordinary role in reasoning concerning family formation. In our sample the goal of 
an independent life appeared to be pursued by both men and women. Parenthood has to be postponed due to longer periods of education, unpredictable career paths, and precarious working conditions for young people, and some participants preferred to explore other countries and to "live their lives" before approaching parenthood. But if a couple has children or is expecting a child and they are a "real" family, this changes dramatically.

In the western German focus groups we find quite contrary views compared to those in the eastern German groups. Interestingly, emotional or romantic reasons to marry played only a minor part in the discussions. The participants were more likely to describe marriage as being closely connected to very particular value judgements related to life in a partnership. The main motivation to get married discussed in the western German groups was for the partner to have an institutionalized commitment that provides an authoritative structure and a secure base for raising children:

Being married means that I have a duty to my wife. I made a commitment which in turn has given her freedom to get involved in getting a child and now she just takes the time to care for this child, at least in the early years and to raise the child because she knows in any case, if everything else fails, I am obligated as her husband to provide her and the child's living [...] (MW18-22, male, 33, west, higher edu., married, children).

This desire to have a written and legally binding commitment to the partner is closely connected to the ideal of a good mother, which is incompatible with female selffulfilment and economic independence based on the mother working full-time. According to the discussion in the western German groups, the priorities of the western German women change after the birth of their first child, from a focus on personal fulfilment to a focus on the well-being of the child and the family.

A number of female participants who had children recounted that since the birth of their (first) child the division of labour in their household had changed dramatically. In a discussion group for western German women with higher educational attainment, Participant FW17-63 explained the changes in the gender roles in a partnership caused by the birth of a child as follows:

It seems that for years we have celebrated the revolution, that even in relationships the partners are equal, and each person should contribute. But when the children arrive, [the gender-based division of labour] just seems to happen automatically, it creeps in. I didn't find it particularly bad, I'm not complaining. But it can of course escalate. Because you spend time with the children, or more time than the man, and because, for example, you are at 
home while taking parental leave and automatically take care of the household, the man learns that he doesn't have to do as much anymore [...]. (FW17-63, female, 39, west, higher edu., single, 1 child)

The observation that the change in the roles of the partners after the birth of the first child is unavoidable ("automatic") is, on the one hand, framed in negative terms and seen as a reversion to traditional (and generally discarded and repudiated) gender roles, for which men are implicitly held partially responsible. After FW17-63 complained "the more children there are" the less men help to clean the house, FW1761 agreed, saying, "Men just don't do it right. If they try they mess it up, or they act as if they don't know how to do it, so that at some point you say, 'Never mind, I'll do it'." On the other hand, the change in roles is seen as an "automatic" consequence of the unquestioned responsibility of a mother for their child. As Participant FW17-65 said in response: "I think you take on this role because you want to take care of the children".

Whereas the men and women in western Germany claimed to be in favour of egalitarian role models that confer and allow both sexes the greatest possible individuality and freedom, the division of paid work and childcare responsibilities between the parents was clearly structured along gender lines within marriage. Alternative roles for mothers, who were seen as the main caregivers, hardly came up in the western German discussions, and were quickly rejected when they were. The women's own aspirations, as well as external expectations, make it difficult for them to choose to behave in ways that would make it necessary for them to outsource childcare.

Especially within the male discussion groups in western Germany, the function of marriage to organise family life was clearly expressed. Thus, most men expressed a willingness to take on the role of the breadwinner, and to provide financially for their wife and children. These men tended to see marriage as a normative legitimation of the gendered division of paid and unpaid work. Marriage is seen as a useful institution that supports the partners in fulfilling their mutual responsibilities. For example, MW18-62 observed that after the birth of their child, his wife can "leave her job for three years" and thus "has time to take care of the child". In his view, the woman should take care of the child, while the man supports the family financially: "We have arranged our life so that we can manage on one income for three years". MW18-63 countered by saying, "The question is whether the woman wants to do that, because she might have professional goals herself", thereby pointing to the potential negative consequences of parenthood for a woman's professional career. MW18-62 reacted to this observation by emphasising the mutual dependence of the partners and the role marriage plays in enabling this arrangement: "Yes, by marrying I have committed to support her, and that was important to her as a form of security before she would agree to have a child and to stay home for the first three years to care for it". MW18-63 agreed with this statement 
and did not criticise the general principle. He noted, however, that if it is assumed that women will be assigned the task of caring for the children, if they decide to have a child "women will then find it relatively difficult" to pursue their professional goals. In conclusion, he observed, "That's why many women don't want to do it, because they also have the goal of getting a leadership position in their company". Like the women mentioned above, it appears that the men in our focus groups cannot imagine a third option in which women use institutional childcare or rely on their male partner to do a greater portion of the childcare and housework.

\section{Summary and discussion}

Our findings show that clear normative differences remain between eastern and western Germany in terms of attitudes towards partnership, marriage, and family formation.

In our eastern German group, marriage is seen as having a comparatively reduced, individualised moral meaning. Nonmarital cohabitation is viewed, in line with Heuveline and Timberlake (2004), as either an alternative to marriage, i.e., as a relatively long and stable union that is similar to marriage and in which children are often born, or as a partnership form that is indistinguishable from marriage and thus fulfils the same functions and is as accepted in society as marriage. Nonmarital cohabitation with children is socially accepted, and is seen as a normal societal reality.

In this context, marriage as an institution has, according to the typology of Holland (2013), above all an emotional meaning for the couple, and is thus seen as an institution that can strengthen and reinforce the commitment of couples who do not get married until sometime after the birth of their first child (or subsequent children). Marriage is therefore not viewed as a precondition for having children, but rather as an additional symbol of the partnership's security and stability, Or, again according to Holland's typology (2013), marriage is regarded as the capstone of the relationship of a couple for whom family formation was completed with the birth of a second or subsequent child, and for whom getting married is simply a symbolic confirmation of a longstanding relationship. In line with Schneider and Rüger (2007), we can contrast the instrumental and spontaneous or emotional motives for getting married on the one hand with the less relevant value-oriented motives on the other.

In our western German discussion groups we saw that although nonmarital cohabitation is accepted in society, it is seen, following the typology of Heuveline and Timberlake (2004), as either a prelude to marriage or a phase in which the relationship is being 'tried out' and during which a child is seldom born, even though in our case this 'trying out' phase can last a very long time; or as a step in the process towards getting married, in which marriage is typically associated with the birth of one or more 
children. Nonmarital cohabitation is also accepted as an alternative to marriage, but only if the couple is childless. Thus, in line with Holland (2013), we find evidence to support the view that marriage is seen as a legitimising institution, and is considered a prerequisite for having children.

The greater sense of commitment associated with getting married that was found among the western German groups is attributable to the normatively weighted, rather specific behavioural expectations of the man and the woman. The western German men identified closely with traditional norms regarding marriage-specific gender roles ("family breadwinner"), and thus with the assumption that the husband should seek to maximise and secure the household income. Meanwhile, the western German women agreed to take on, albeit somewhat reluctantly, the role of the housewife and mother who has the primary responsibility for the children. Those who did not want to follow this model saw themselves as having to defend their position, as they recognised the normative strength and binding force of this model. In line with the findings of Schneider and Rüger (2007), our results show that the value-oriented motivations for getting married dominated.

For western German women in particular, this means that when a woman becomes a mother (and, usually, gets married) there is a sharp break in her life trajectory. Up to this point, a woman is permitted to prioritise her personal fulfilment and freedom. Thus, having had a long and intensive phase during which can pursue her personal goals is seen as an important precondition for a woman becoming a mother. After the birth of the first child, family and children become the focus of the woman's life and replace her individual life pursuits. Women in eastern Germany, by contrast, expect to be able to combine motherhood with other goals. They do not feel that they are faced with an either/or proposition; instead, they believe they can have a family as well as a personal and professional life. Among the female (and male!) participants in the eastern German discussion groups, the idea that a woman's life might be divided into two separate parts was considered laughable, and was viewed as an absurd way for a woman to plan her life.

We also asked about the extent to which the different behavioural patterns simply represent a continuation of traditional patterns, and the extent to which men and women are modifying and transforming their behaviour in response to changing conditions. In line with the Theory of Structuration (Giddens 2013), we expected to find that there would be regional differences in the ways in which people were adjusting to the new (harmonised) conditions, which arose from their specific biographical experiences. Our results show that traditional patterns of behaviour in the east and the west are seen as irrational under current conditions (e.g., early marriage in eastern Germany) or as associated with high opportunity costs (e.g., marriage tied to a re-traditionalisation of gender roles in western Germany). 
In the east the participants reported that many of the societal privileges associated with marriage had disappeared, along with the instrumental reasons for marriage that made getting married attractive in the GDR. Today, eastern Germans get married mainly if it makes sense to do so because individual reasons, such as affectualemotional motives, compensate for this loss of meaning. In the west, by contrast, the participants reported that they were trying to conform with or to return to traditional patterns of behaviour and gender roles, even as the simultaneous ascendancy of modern, individualistic, and emancipatory norms and values create enormous internal tensions that cannot be easily resolved.

The results for the eastern German discussion groups can be summarised under the heading, 'a modernised rationalisation of traditional behavioural patterns'. Modern norms and values and traditional behavioural patterns are combined in a new logical framework for everyday behaviour. The comparatively high labour market participation rates among women are not attributed to the role models of the parents' and grandparents' generations, but are rather justified with reference to values such as emancipation, independence, and personal fulfilment. The prevailing belief among eastern Germans that women should be able to have both a family and personal and professional goals fits within the logic of the current discourse, and not just rhetorically: by forgoing having a second or a third child, women are taking the demands of the modern workplace into account. The behaviour of eastern German women cannot be seen solely as a continuation of the traditions of the GDR or simply as a response to current conditions, but rather as a pattern that has evolved out of a mixture of these different influences.

In western Germany we find a concurrence of tradition and modernity. Traditional behavioural patterns and modernised values and norms are equally accepted in society, but they cannot be combined. A woman must either accept that there will be a break in her life trajectory, or she has to suppress her desire to have children. A clear consequence of this development is that many women choose to delay or even forego having children, with each woman making this choice by weighing up the competing life goals of personal and professional fulfilment on the one hand and having children on the other.

This study has a few limitations. First, the sample is not representative and the focus groups were held in cities in the north of Germany and not across different regions and urban and rural settings of Germany. However, Rostock and Lübeck are very typical medium-sized cities, the family and tax policies in Germany are uniform across Germany, and the GDR policies referred to by many of our respondents were uniform across the whole of eastern Germany until 1990. We stratified our sample by gender and education. The participants lived in various union arrangements (partnership, married, single) with or without children, and differed considerably by 
age. They had very different living situations and life experiences. Thus, we are confident that our main conclusions hold true for Germany as a whole. For southern parts of western Germany we might expect even more pronounced differences with the eastern German respondents. Second, the method of focus groups does not allow drawing conclusions about the process of individual decision-making regarding the choice between marriage and cohabitation. However, focus groups are an ideal method for eliciting commonly shared social norms. The methods shows how strong these norms are and how strictly they are sanctioned, thus giving more information about the context of individual decisions. Third, the focus groups in Rostock were larger than the groups in Lübeck and the total number of eastern German respondents was higher. Yet, according to the methodological literature, the ideal size of focus groups is between 5 and 10 persons, and our groups in western Germany had at least 5 participants. The methodological literature and our own research experience show that even in smaller groups there is enough variation in attitudes to spur a lively debate on social norms. Fourth, we conducted eight homogeneous groups with respondents born and raised in eastern Germany, but only five homogeneous groups in western Germany. This might raise the question of whether the sample was unbalanced. Yet, following the concept of theoretical saturation derived from Grounded Theory (Glaser and Strauss 1967), we are confident that we reached a point in data collection where further data would not contribute to the enrichment of our findings nor yield new information. Nor did our mixed groups consisting of both eastern and western German respondents elicit new insights: instead they corroborated our analysis.

To conclude, our assumption that we would see regional differences in social norms despite the harmonised legal context was confirmed. These norms are strongly influenced by structural and legal conditions, but the ways in which these conditions affect the everyday and biographical practices of men and women are subject to the personal and intergenerational experiences of individuals and the influence of other social relationships and contexts. The harmonisation of family and political regulations after the unification of Germany in 1990 did not automatically lead to a convergence in the behaviour of the subpopulations living in the two regions. This suggests that the differences in norms and values continue to influence behavioural patterns: an insight that future research on marriage and family should take into account.

\section{Acknowledgements}

This research was funded by Brienna Perelli-Harris's ERC starting grant CHILDCOHAB. The authors are very grateful to Daniela Georges, who assisted in conducting the focus groups and performed the first round of coding of the material. 
The article benefited from discussions with Focus on Partnership team members during workshops. We are grateful to Brienna Perelli-Harris, Laura Bernardi, and three anonymous reviewers of Demographic Research for their valuable comments. 


\section{References}

Arránz Becker, O., Lois, D., and Nauck, B. (2010). Differences in fertility patterns between East and West German women: Disentangling the roles of cultural background and of the transformation process. Comparative Population Studies 35(1): 7-34.

Barbour, R. (2007). Doing focus groups. Los Angeles: Sage. doi:10.4135/978184 9208956.

Bastin, S., Kreyenfeld, M., and Schnor, C. (2013). Diversität von Familienformen in Ost- und Westdeutschland. In: Herma, H., Schierbaum, A., and Krüger, D. (eds.). Familie(n) heute. Weinheim: Beltz Juventa: 126-145.

Beck-Gernsheim, E. (2002). Reinventing the family: In search of new lifestyles. Cambridge: Polity.

Bernardi, L., Klärner, A., and von der Lippe, H. (2008). Job insecurity and the timing of parenthood: A comparison between eastern and western Germany. European Journal of Population 24(3): 287-313. doi:10.1007/s10680-007-9127-5.

Bloor, M., Frankland, J., Thomas, M., and Robson, K. (2001). Focus groups in social research. London: Sage. doi:10.4135/9781849209175.

Diabaté, S. and Lück, D. (2014). Familienleitbilder: Identifikation und Wirkungsweise auf generatives Verhalten. Zeitschrift für Familienforschung 26(1): 49-69. doi:10.3224/zff.v26i1.15915.

Falk, S. and Schaeper, H. (2001). Erwerbsverläufe von ost- und westdeutschen Müttern im Vergleich: Ein Land - ein Muster? In: Bom, C. and Krüger, H. (eds.). Individualisierung und Verflechtung: Geschlecht und Generation im deutschen Lebenslaufregime. Weinheim: Beltz Juventa: 181-210.

Giddens, A. (2013). The constitution of society: Outline of the theory of structuration. Oxford: Wiley.

Glaser, B. and Strauss, A. (1967). The discovery of grounded theory. London: Weidenfield \& Nicolson: 1-19.

Heuveline, P. and Timberlake, J.M. (2004). The role of cohabitation in family formation: The United States in comparative perspective. Journal of Marriage and the Family 66(5): 1214-1230. doi:10.1111/j.0022-2445.2004.00088.x. 
Hiekel, N., Liefbroer, A.C., and Poortman, A.-R. (2014). Understanding diversity in the meaning of cohabitation across Europe. European Journal of Population 30(4): 391-410. doi:10.1007/s10680-014-9321-1.

Hill, P.B. and Kopp, J. (2013). Familiensoziologie: Grundlagen und theoretische Perspektiven. Wiesbaden: Springer. doi:10.1007/978-3-531-94269-8.

Holland, J.A. (2013). Love, marriage, then the baby carriage? Marriage timing and childbearing in Sweden. Demographic Research 29(11): 275-306. doi:10.4054/ DemRes.2013.29.11.

Holst, E. and Schupp, J. (2001). Employment behaviour among women in Germany. Economic Bulletin 38(11): 377-384. doi:10.1007/s101600170001.

Huinink, J., Kreyenfeld, M., and Trappe, H. (2012). Familie und Partnerschaft in Ostund Westdeutschland. Eine Bilanz. In: Huinink, J., Kreyenfeld, M., and Trappe, H. (eds.). Familie und Partnerschaft in Ost- und Westdeutschland: Ähnlich und doch immer noch anders. Opladen: Budrich: 9-28.

Hülser, O. (1996). Frauenerwerbstätigkeit im Transformationsprozeß der deutschen Vereinigung. Nürnberg: Institut für Arbeitsmarkt- und Berufsforschung der Bundesanstalt für Arbeit (IAB).

Inglehart, R. (1977). The silent revolution: Changing values and politic styles among western publics. Princeton: Princeton University Press.

Kalmijn, M. (2007). Explaining cross-national differences in marriage, cohabitation, and divorce in Europe, 1990-2000. Population Studies 61(3): 243-263. doi:10.1080/00324720701571806.

Kiernan, K. (2004). Unmarried cohabitation and parenthood in Britain and Europe. Law \& Policy 26(1): 33-55. doi:10.1111/j.0265-8240.2004.00162.x.

Klärner, A. (2015). The low importance of marriage in eastern Germany: Social norms and the role of peoples' perceptions of the past. Demographic Research 33(9): 239-272. doi:10.4054/DemRes.2015.33.9.

Klärner, A. and Keim, S. (2011). (Re-)Traditionalisierung und Flexibilität: Intergenerationale Unterstützungsleistungen und die Reproduktion von Geschlechterungleichheiten in West- und Ostdeutschland. In: Berger, P.A., Hank, K., and Tölke, A. (eds.). Reproduktion von Ungleichheit durch Arbeit und Familie. Wiesbaden: Springer: 121-144. doi:10.1007/978-3-531-94117-2_6. 
Kolinsky, E. (2003). Gender and the limits of equality in eastern Germany. In: Kolinsky, E. and Nickel, H.M. (eds.). Reinventing gender? Women in eastern Germany since unification. London: Frank Cass: 100-127.

Konietzka, D. and Kreyenfeld, M. (2004). Angleichung oder Verfestigung von Differenzen? Geburtenentwicklung und Familienformen in Ost- und Westdeutschland. Berliner Debatte Initial 15(4): 26-41.

Konietzka, D. and Kreyenfeld, M. (2010). The growing educational divide in mothers' employment: An investigation based on the German micro-censuses 1976-2004. Work, Employment and Society 24(2): 260-278. doi:10.1177/09500170103 62140 .

Kreyenfeld, M. (2004). Fertility decisions in the FRG and GDR: An analysis with data from the German Fertility and Family Survey. Demographic Research Special Collection 3(11): 276-318. doi:10.4054/demres.2004.s3.11.

Klüsener, S. and Goldstein, J.R. (2014). A long-standing demographic east-west divide in Germany. Population, Space and Place 22(1): 5-22. doi:10.1002/psp.1870.

Leitner, S., Ostner, I., and Schmitt, C. (2008). Family policies in Germany. In: Ostner, I. and Schmitt, C. (eds.). Family policies in the context of family change: The nordic countries in comparative perspective. Wiesbaden: VS Verlag für Sozialwissenschaften: 175-202. doi:10.1007/978-3-531-90895-3_9.

Lesthaeghe, R. (2010). The unfolding story of the Second Demographic Transition. Population and Development Review 36(2): 211-251. doi:10.1111/j.1728-4457. 2010.00328.x.

Lesthaeghe, R. (2011). The "second demographic transition": A conceptual map for the understanding of late modern demographic developments in fertility and family formation. Historical Social Research 36(2): 179-218.

Liamputtong, P. (2011). Focus group methodology: Principles and practice. London: Sage. doi:10.4135/9781473957657.

Liefbroer, A.C., Merz, E.-M., and Testa, M.R. (2015). Fertility-related norms across Europe: A multi-level analysis. In: Philipov, D., Liefbroer, A.C., and Klobas, J.E. (eds.). Reproductive decision-making in a macro-micro perspective. Dordrecht: Springer: 141-163. doi:10.1007/978-94-017-9401-5_6. 
Nave-Herz, R. (1989). Zeitgeschichtlicher Bedeutungswandel von Ehe und Familie in der Bundesrepublik Deutschland. In: Nave-Herz, R. and Markefka, M. (eds.). Familienforschung: Handbuch der Familien- und Jugendforschung. Neuwied: Luchterhand: 211-222.

Nave-Herz, R. (ed.) (2001). Wandel und Kontinuität der Familie in der Bundesrepublik Deutschland. Stuttgart: Enke.

Perelli-Harris, B., Kreyenfeld, M., Sigle-Rushton, W., Keizer, R., Lappegård, T., Jasilioniene, A., Berghammer, C., and Di Giulio, P. (2012). Changes in union status during the transition to parenthood in eleven European countries, 1970s to Early 2000s. Population Studies 66(2): 167-182. doi:10.1080/00324728. 2012.673004 .

Perelli-Harris, B. and Lyons-Amos, M. (2015). Changes in partnership patterns across the life course. Demographic Research 33(6): 145-178. doi:10.4054/DemRes. 2015.33.6.

Perelli-Harris, B., Mynarska, M., Berrington, A., Berghammer, C., Evans, A., Isupova, O., Keizer, R., Klärner, A., Lappegård, T., and Vignoli, D. (2014). Towards a new understanding of cohabitation: Insights from focus group research across Europe and Australia. Demographic Research 31(34): 1043-1078. doi:10.4054/ DemRes.2014.31.34.

Peuckert, R. (2012). Familienformen im sozialen Wandel. Wiesbaden: Springer. doi:10.1007/978-3-531-19031-0.

Pfau-Effinger, B. and Geissler, B. (2002). Cultural change and family policies in East and West Germany. In: Carling, A., Duncan, S., and Edwards, R. (eds.). Analysing families: Morality and rationality in policy and practice. London: Routledge: $77-83$.

Pfau-Effinger, B. and Smidt, M. (2011). Differences in women's employment patterns and family policies: Eastern and western Germany. Community, Work \& Family 14(2): 217-232. doi:10.1080/13668803.2011.571401.

Pollmann-Schult, M. (2009). Arbeitszeitwunsch und -wirklichkeit im Familienkontext: Eine Analyse der Diskrepanzen zwischen präferierter und tatsächlicher Arbeitszeit. Soziale Welt 60(2): 163-178. doi:10.5771/0038-6073-2009-2-163.

Rüling, A. (2007). Jenseits der Traditionalisierungsfallen: Wie Eltern sich Familienund Erwerbsarbeit teilen. New York: Campus. 
Schmitt, C. and Trappe, H. (2010). Die Bedeutung von Geschlechterarrangements für Partnerschaftsdauer und Ehestabilität in Ost- und Westdeutschland. In: Krause, P. and Ostner, I. (eds.). Leben in Ost- und Westdeutschland. Frankfurt am Main: Campus: 227-246.

Schneider, N.F. and Rüger, H. (2007). Value of marriage: Der subjektive Sinn der Ehe und die Entscheidung zur Heirat. Zeitschrift für Soziologie 36(2): 131-152.

Schneider, N., Diabaté, S., and Ruckdeschel, K. (2015). Familienleitbilder in Deutschland: Kulturelle Vorstellungen zu Partnerschaft, Elternschaft und Familienleben. Opladen: Budrich.

Schnor, C. (2012). Trennungsrisiko von Paaren mit Kindern: Der Einfluss der Religion in West-und Ostdeutschland. Zeitschrift für Familienforschung (Special Issue 9): 229-256.

Schnor, C. (2014). The effect of union status at first childbirth on union stability: Evidence from eastern and western Germany. European Journal of Population 30(2): 129-160. doi:10.1007/s10680-013-9304-7.

Sobotka, T. and Toulemon, L. (2008). Changing family and partnership behaviour: Common trends and persistent diversity across Europe. Demographic Research 19(6): 85-138. doi:10.4054/DemRes.2008.19.6.

Stewart, D.W., Shamdasani, P.N., and Rook, D.W. (2007). Focus groups: Theory and practice. Thousand Oaks: Sage. doi:10.4135/9781412991841.

Surkyn, J. and Lesthaeghe, R. (2004). Value orientations and the Second Demographic Transition (SDT) in northern, western and southern Europe: An update. Demographic Research Special Collection 3(3): 45-75. doi:10.4054/DemRes. 2004.S3.3.

Thornton, A., Axinn, W.G., and Xie, Y. (2007). Marriage and cohabitation. Chicago: University of Chicago Press. doi:10.7208/chicago/9780226798684.001.0001.

Träger, J. (2009). Familie im Umbruch: Quantitative und qualitative Befunde zur Wahl von Familienmodellen. Wiesbaden: Springer. doi:10.1007/978-3-531-91362-9.

Trappe, H. (1995). Emanzipation oder Zwang? Frauen in der DDR zwischen Beruf, Familie und Sozialpolitik. Berlin: Akademie.

Trappe, H. and Sørensen, A. (2006). Economic relations between women and their partners: An East and West German comparison after reunification. Feminist Economics 12(4): 643-665. doi:10.1080/13545700600885255. 
Treas, J., Lui, J., and Gubernskaya, Z. (2014). Attitudes on marriage and new relationships: Cross-national evidence on the deinstitutionalization of marriage. Demographic Research 30(54): 1495-1526. doi:10.4054/DemRes.2014.30.54.

van de Kaa, D.J. (1987). Europe's second demographic transition. Population Bulletin of the United Nations 42(1): 1-59.

van de Kaa, D.J. (2001). Postmodern fertility preferences: From changing value orientation to new behavior. Population and Development Review 27: 290-331.

Vaskovics, L.A. and Rupp, M. (1995). Partnerschaftskarrieren: Entwicklungspfade nichtehelicher Lebensgemeinschaften. Opladen: Westdeutscher Verlag. doi:10.1007/978-3-322-95642-2.

Werneck, H., Beham, M., and Palz, D. (ed.). (2006). Aktive Vaterschaft: Männer zwischen Familie und Beruf. Gießen: Psychosozial-Verlag. 